\title{
FLOUTING MAXIMS ON THE DIALOGUE OF CHARACTERS IN UP! ANIMATED MOVIE
}

\author{
Perni Giriyani ${ }^{1}$, Efransyah ${ }^{2}$ \\ ${ }^{1}$ IKIP Siliwangi \\ ${ }^{2}$ IKIP Siliwangi \\ ${ }^{1}$ pernigiriyani09@student.ikipsiliwangi.ac.id, ${ }^{2}$ efransbae@gmail.com
}

\begin{abstract}
Good communication is guided in pragmatic that is called cooperative principles. This principle is supported by four maxims namely, quantity, quality, relevant, and manner. This research is about flouting maxims on the dialogue of characters in UP! animated movie. Hence, it is aimed to know flouting maxim on UP! animated movie. Qualitative research used in this research. The data of this study was taken on flouting maxims on the discourse of figure in UP! animated movie from he main characters namely old name Carl Fredrickson and Russel. There are several steps in collecting the data namely, finding a script UP! of the animated movie, next is analyzing the script with the UP! movie and the last is to list the utterances of the main personality of UP! animated movie in flouted maxims and finally analyzing them based on the chosen theory. After conducting the research, the writer found 20 sentences that flouted by Mr. Fredickson and Russel animated UP! movie. Those kinds of maxims are 6 flouted maxims of quantity, 7 flouted maxims of quality, 3 flouted maxims of relevance, and 4 flouted maxims of manner.
\end{abstract}

Keywords: Flouting maxim, Dialogue, Movie

\section{INTRODUCTION}

Language is a human facilitator to communicate with others in the world. In our daily life, we interact with each other to acquire information. In this case, Efransyah (2018) stated that terms are a resource for meaning-making. That is why when anyone speaks using a language, she or he constructs or produces a meaning. Darmadi (2015) as cited in Parmawati and Inayah (2019) defines speaking as a productive skill that can be observed directly and empirically. Furthermore, Sharma, S \& Rachna (2015) revealed that communication is originated from the Latin word "communicate" which means to share information can be conveyed and understood through the progress of communication. In sending the messages, we have to deliver them shortly, clearly and effectively in the order, they are easily understood because sometimes people concern to talk without thinking about it well. That is why selecting a proper word is an important thing to do.

Good communication is guided in pragmatic that is called cooperative principles. This principle is supported by four maxims namely, quantity, quality, relevant, and manner. According to Cook (1989:29) in Adawiyah (2016) declared that maxim quantity regulates that the talker is supposed to contribute as more informative or less informative as is needed. The second maxim regulates that a speaker has to speak the truth not to tell something that is trusted to be false adequate evidence. And the third one means that a speaker has related to the topic under discussion. While the last maxim is defined that the teller should avoid vagueness of expression, avoid ambiguity, be brief, and be orderly.

In this research, the writers took the information from a movie script entitled UP! and they wanted to analyze kinds of maxims and those which are flouted in that movie. According to 
Nuringtyas (2018), Flouting maxim can be established in drama, short story, talkshow, and standup comedy, that is why the writers chose the movie to be the data in their research that Pixar animation studios produced animated UP! movie and directed by Pete Doctor. Also, Jia (2008) in Sobhani \& Saghebi (2014) stated that the flouting maxims also can be described as occasions when one or several maxims are absent during communication processes.

According to Alfina, Ester O \& Subiyanto (2016) maxim of quantity requires the speaker to make a contribution that is an issue required, the second is quality maxim requires expressions that have enough fact, the third is the pattern of this maxim should be relevant to the topic, this maxim must relevance between the speaker and the hearer and the last is a maxim of manner requires contribution that is clear, brief, orderly, and unambiguous.

In line with this Ibrahim, et al (2018) in the maxim of quantity, their contribution informative as required is made by the talker, which means that the information is neither given too much by the speaker. And maxim quality can be explained as truthful. It means that the information must be delivered by the speaker that it is true. While in the maxim of relevance, the speakers are required to be related in saying something. The speakers are expected to tell something suitable to what is said before, and the last Grice argues that the speechmaker tends to be clearly, be orderly, to avoid uncertainty and obscurity of expression. It measures that the speaker must say something clearly.

According to Setiawan \& Haryani, (2020) the contribution an informative as recommended maxim of quantity challenging should be given by the participants. Maxim of quality demanding the participants should give honest and truthful statement. Maxim of relation asking the participant to reply relevantly regarding to the topic of communication. And the last maxim of manner suggests the colleague of the conversation to be perspicuous, avoid obscurity, avoid ambiguity, and avoid unnecessary prolixity.

\section{METHOD}

This paper is used qualitative research method. According to Taylor (1984) as cited in Efransyah (2020) "the researcher develop concept, insight, and understanding from the pattern in the data rather than assess preconceived models, hypothesis or theories in qualitative method". Cropley, (2019) In qualitative studies, the initial steps in designing a research project - defining just what will be investigated, selecting an appropriate data-collection method and identifying appropriate participants. Therefore, in analyzing qualitative data requires understanding how to make sense of text and image, so that you can form answers to your research questions (Creswell cited in Aryana \& Apsari, 2018). The data of this analysis is taken on flouting maxims on the script of characters in UP! Animated movie. In analyzing those flouting maxims on animated of UP! movie, the writers used Grice's theory.

\section{RESULTS AND DISCUSSION}

\section{Results}

From the plural result of the data, the writers revealed them as follow:

Table 1

The flouting maxim on the dialogue of characters in UP! Movie animated

\begin{tabular}{llllll}
$\begin{array}{l}\text { Name of } \\
\text { characters }\end{array}$ & $\begin{array}{l}\text { Flouting } \\
\text { maxim } \\
\text { quantity }\end{array}$ & $\begin{array}{l}\text { Flouting } \\
\text { maxim } \\
\text { quality }\end{array}$ & $\begin{array}{l}\text { Flouting } \\
\text { maxim } \\
\text { relevance }\end{array}$ & $\begin{array}{l}\text { Flouting } \\
\text { maxim } \\
\text { manner }\end{array}$ & $\begin{array}{l}\text { The amount } \\
\text { of flouted } \\
\text { sentences }\end{array}$ \\
\hline
\end{tabular}




\begin{tabular}{lllllc} 
Fredickson & 1 & 6 & 3 & 2 & 12 \\
Russel & 5 & 1 & - & 2 & 8 \\
\hline Total & & & & 20 \\
\hline
\end{tabular}

The writer found 20 sentences that flouted on the significant of player Mr. Fredickson and Russell of UP animated movie. Those are 6 flouted maxims of quantity, 7 flouted maxims of quality, 3 flouted maxims of relevance and 4 flouted maxims of manner.

\section{Discussion}

From the results of the data finding above, the writer interpreted them as follow:

Table 2

\section{The Flouting of Maxim Quantity}

\begin{tabular}{|c|c|c|}
\hline$\overline{\text { No }}$ & Conversation & Reason \\
\hline 1 & 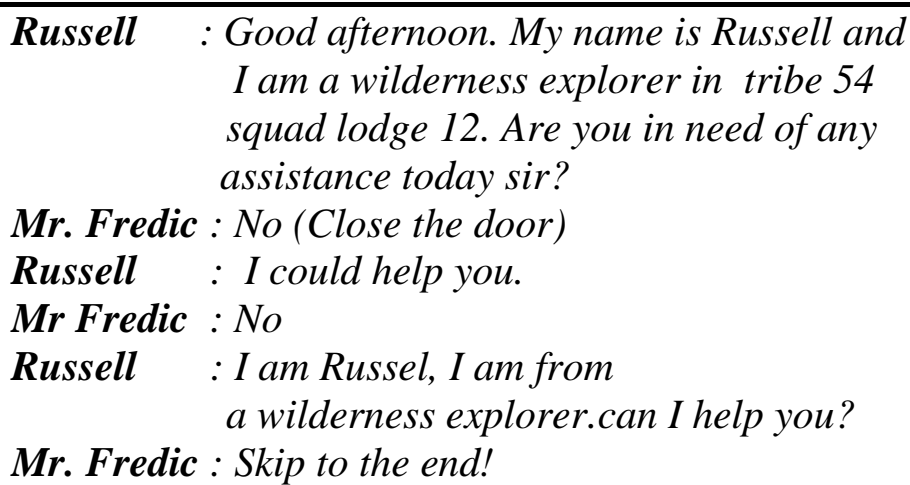 & $\begin{array}{l}\text { Russel instroduced } \\
\text { himself repeteadly. So } \\
\text { that Mr. Fredickson } \\
\text { became bored and angry } \\
\text { because the speech was } \\
\text { very long. }\end{array}$ \\
\hline 2 & $\begin{array}{cc}\text { John } & \text { Hi good morning Mr. Fredickson. } \\
& \text { Need any help there? } \\
\text { Mr Fredic }: & \text { No. Oh yes talk to your boss } \\
& \text { that you boys are disturbing me. }\end{array}$ & $\begin{array}{l}\text { Mr. Fredickson's answer } \\
\text { is not consistent. He } \\
\text { changed his mind fast }\end{array}$ \\
\hline
\end{tabular}

Tabel 3

The Flouting Maxim of Quality

\begin{tabular}{|c|c|c|}
\hline No & Conversation & Reason \\
\hline 1 & $\begin{array}{c}\text { Russel } \quad \text { Can I give my hand? } \\
\text { See these? These are my wilderness } \\
\text { explorer badges. You may put } \\
\text { one is missing. It's my "assisting the } \\
\text { elderly badge "If I get it, I am proud } \\
\text { of becoming an explorer! } \\
\text { Mr. Fredic : Did you hear a Snipe? A bird } \\
\text { big eyes, every night it sneaks into my } \\
\text { yard. I am old enough and infirm, } \\
\text { I wish someone could catch it for me. }\end{array}$ & $\begin{array}{l}\text { From the data Mr. Fredic } \\
\text { flouts maxim of quality. } \\
\text { Because he lied or tells } \\
\text { something not true that } \\
\text { there a bird namely Snipe } \\
\text { In this situation. He tries } \\
\text { not to be bothered by } \\
\text { Russell. }\end{array}$ \\
\hline
\end{tabular}


2 The enemy : Shoot him, shoot him!

Russell : Hey Squirrel
Russell was forced to lie to an enemy who was

Afraid of squirrels. So that he safe from the enemy.

Tabel 4

The Flouting Maxim of Relevant

\begin{tabular}{ccl}
\hline No & Conversation & \multicolumn{1}{c}{ Reason } \\
\hline 1 & Russell & : Why do we go to paradise fall \\
& Mr. Fredickson? & Mr. Fredicskon change \\
& Mr. Fredic : Oh let's play the game, whoever is & The answer and did not \\
& silent is the winner. & answer question from \\
& Russell. The talker does \\
& not want to continue \\
& speaking on the same topic \\
& then he change the topic or \\
& avoids by talking \\
& something else.
\end{tabular}

2 Russell : I see that cloud. It is a

"cumulonimbus". Did you know

Mr. Fredickson did not

that a comulinimbus?

respond Russel's question, And he explained another

Mr Fredic : Aaaa I stayed up all night blowing thing to Russel. up ballons.

Tabel 5

The Flouting Maxim of Manner

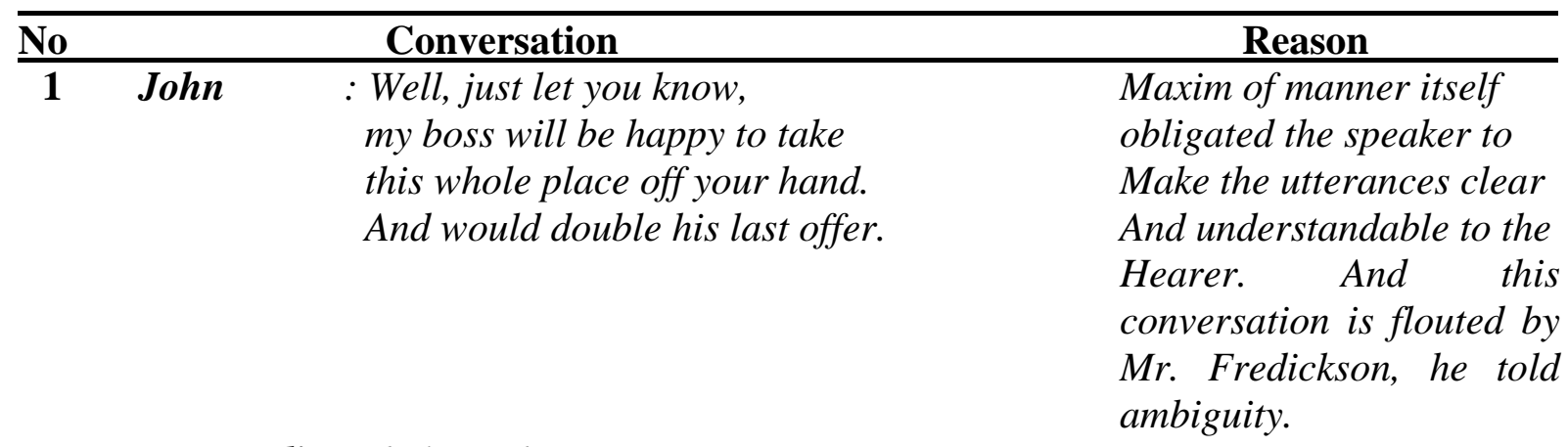

Mr. Fredic : I believe that

your boss understanding about

I am saying. Here, let me talk to him.

You in the suit.Yes you! Go away

From my house! hippie!

\begin{tabular}{ll}
\hline 2 Russsel & : Can we keep him? Please! \\
& I'll get the food for him, I'll \\
& walk him, I will change his \\
& newspapers
\end{tabular}

Mr. Fredic : No
Russel explained that he want to keep the bird,but he said an ambiguity to $M r$. Fredickson when he was begging to him.




\section{Russel : An adventurer is a friend to all, be it plant, a fish or a tiny mole.}

\section{CONCLUSION}

This research is conducted to idenity the types of maxims which are flouted by the main characters' in UP! animated movie. Those maxims are Quantity, quality, relevance, and manner. The flouted maxim of quantity is recognized when the character talked very long to the other people. They should produce an expression briefly or shortly in order it could easily to be understood. The second one, flouted maxim of quality, is identified when the characters speak something that is not facts or lies. The third, namely flout maxim of relevance is known when the characters changed the topic of a conversation to the other one. The last, flouted maxim of manner is also recognized when the characters speak something unclear or ambiguous so they cannot be understood by the listeners.

\section{ACKNOWLEDGMENTS}

Firstly, I would like to thanks to Allah SWT who has given me a strength in completing my research, the second I say thanks to my parents who has supported me to keep moving in this research, the third and the next I shall like to thanks to my supervisor who has helped me until this research published, and the rest I also feel like to thank to my friends who has helped me in doing this research that I cannot mention one by one.

\section{REFERENCES}

Adawiyah, R. (2016). Flouting Maxim Used By The Main Characters In "Focus " Movie. Maulana Malik Ibrahim State Islamic University Of Malang.

Alfina, Ester Okta, Subiyanto, A. (2016). The Maxim Violation On Mata Najwa Talk Show 'Selebriti Pengganda Simpati '. In Diponegoro University: Vol. 5 (2). Diponegoro Univesity Semarag.

Aryana, S., \& Apsari, Y. (2018). Analysing Teacher's Difficulties In Teaching Listening. Eltin Journal, Journal Of English Language Teaching In Indonesia, 6(2), 100-106.

Cropley, A. (2019). Wholebook Quali.

Efransyah, E. (2018). Analyzing Thematic Structure In Indonesian Folktales In English Version: A Systemic Functional Grammar (Sfg). Project (Professional Journal Of English Education), 1(2), 85-94.

Efransyah, E. (2020). Connotative Meaning In The Proverbs Of The Besemah Language (A Sematic Study). Project (Professional Journal Of English Education), 3(1), 143-148.

Ibrahim, Zufah Arifin, Bahri M. Ririn, S. (2018). The Flouting Of Maxim In The Se7en Movie Script. Jurnal Ilmu Budaya, 2(1), 81-94.

Nuringtyas, S. (2018). Flouting Maxim Analysis On Dialogue Of Characters In Pitch Perfect Movie. Universitas As Muhammadiyah Surakarta.

Parmawati, A., \& Inayah, R. (2019). Improving Students'speaking Skill Through English Movie In Scope Of Speaking For General Communication. Eltin Journal, Journal of English Language Teaching In Indonesia, 7(2), 43-53.

Setiawan, F. A., \& Haryani, H. (2020). An Analysis Of Maxim Flouting In Pokémon: Detective Pikachu Movie. Project (Professional Journal Of English Education), 3(2), 224. Https://Doi.Org/10.22460/Project.V3i2.P224-230 
Sharma, Suchi. \& Rachna. (2015). Effective Communication. Scholarly Research Journal For Interdiciplinary Studies, 3(17), 3151-3156.

Sobhani, A., \& Saghebi, A. (2014). The Violation Of Cooperative Principles And Four Maxims In Iranian Psychological Consultation. Open Journal Of Modern Linguistics, 04(01), 9199. 